\title{
РОЗВИТОК СВІДОМОСТІ ОСОБИСТОСТІ ЯК СТРАТЕГІЧНА МЕТА СУЧАСНОÏ ОСВІТИ
}

Наукова доповід ь на загальних зборах НАПН України 17 грудня 2019 р. https://doi.org/10.37472/2707-305X-2019-1-1-1-7

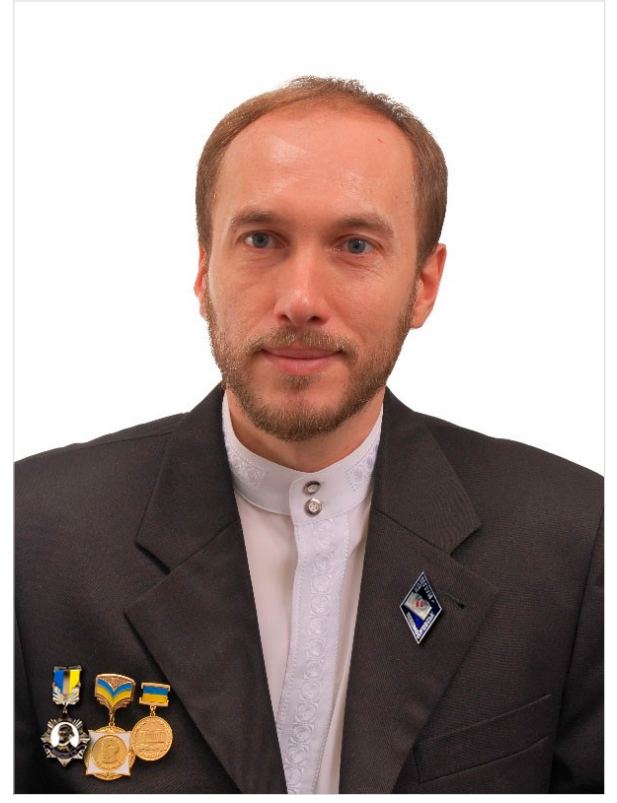

\section{ПОМИТКІН}

\section{Едуард Олександрович}

доктор психологічних наук, професор, завідувач відділу психології праці Інституту педагогічної освіти і освіти дорослих імені Івана Зязюна Національної академії педагогічних наук України, м. Київ, Україна

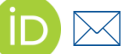

Анотація. Актуалізується проблема модернізації освіти через перехід від знаннєво-репродуктивної парадигми до нової парадигми розвитку свідомості особистості. У цьому контексті війни, корупція і стан екології в Україні розглядаються як наслідок низького рівня свідомості людини. Прикладом освітніх інновацій, розроблених на вказаних засадах, подається інтегративний курс "Людина. Родина. Світ», Дистанційна школа демократії та громадянського суспільства. Наголошується на нагальній необхінності балансування змісту освіти у відповідності до потреб розвитку особистості.

Ключові слова: особистість; свідомість; розвиток; модернізація освіти.

Шановні учасники зборів! Свій виступ я хотів би розпочати $з$ таких тверджень:

«Світ змінюється щомиті. Завдання науки прогнозувати ці зміни. Завдання освіти готувати людину до життя в умовах змін».

Під час доповіді я намагатимуся дати відповіді на три запитання:

- Які перетворення у світі визначають наше майбутнє?

- Чи сприяє сучасна освіта розвитку готовності людини до розв'язання головних проблем сьогодення?

- Яку роль має відігравати наука у модернізації освіти?

Безперечно, однією з провідних ознак сучасного світу є прорив у технологічній сфері. На сьогодні ми маємо розвинену індустрію, комп'ютерні технології, роботизацію. Побут стає комфортнішим, але чи стає світ безпечнішим?

У виступі на засіданні ООН у 2016 р. людиноподібний робот Софія заявила: «Ми розумніші і націлені на безпрограшний результат, тому штучний інтелект здатний ефективно розподілити наявні у світі ресурси, наприклад їжу і воду». На запитання: «Чи будеш ти вбивати людей?» вона дала позитивну відповідь. А в квітні 2017 р., виступаючи на американському телебаченні, поділилася бажанням захопити світ, проте додала, що це жарт. Та не можна назвати жартом будівництво міста роботів Neom на території Саудівської Аравії. Ці роботи отримають громадянство. До речі Росія готова вкласти в цей проект кілька мільярдів доларів.

Чи вкладаються такі ж великі гроші у розвиток самої людини, розв'язання головних проблем їі життя? Які це проблеми? Наше дослідження за участю дорослих і школярів засвідчило, що головними проблемами в Україні $є$ військові дії, корупція, здоров'я громадян та екологія планети. 
Президент України Володимир Зеленський 14 грудня 2019 р. представив «Формулу майбутнього для України». У цій формулі $є$ п'ять складових. Перша з них - мир. Друга - перемога над корупцією та справедливі суди. Третя - інвестиції. Четверта - народовладдя, демократизація суспільства. П'ята - якісна інфраструктура.

Дані соціологічного опитування, проведеного у листопаді 2019 р. Центром Разумкова, свідчать, що 75,2 \% респондентів вірять у можливість подолання Україною існуючих проблем. Проте на запитання, яким чином це має статися більшість відповіді не знає.

Тим часом діти на окупованих територіях 3 перших років життя бачать в руках батьків зброю і звикають до війни. Замість історії України вони вивчають «історію Донецького краю» і Росії. У програмах навчання немає поняття «Київська Русь» - замість неї просто «Русь». Якщо раніше близько 50 \% шкіл були україномовними, то зараз таких шкіл $3 \%$. Чи має освіта і наука брати участь у розв'язанні проблеми припинення війни? Безумовно!

Чи мають освіта і наука брати участь у подоланні корупції? Більшість респондентів подолання корупції розуміє як звернення до засобів масової інформації або повідомлення у соціальних мережах про випадки недоброчесної поведінки державних посадовців. Але хіба схильність до хабарництва не є результатом нечесності, жадібності, низького рівня свідомості? Якщо так, це, безумовно, питання освіти!

Щодо проблеми здоров'я і екології - ії актуальність зростає в усьому світі. У Тихому океані острови сміття дорівнюють своєю площею території Франції. На саміті ООН 16-річна школярка ґрета Тунберґ звинуватила світових лідерів у недостатній боротьбі зі змінами клімату. Діти вимагають від дорослих своє право жити в чистому світі. Згідно з найгіршими прогнозами екологів за 20 років степ наблизиться до межі м. Києва, за 50 - м. Дніпро обміліє вдвічі, а за 100 - країна може залишитися без лісів.

Чи не $є$ розвиток екологічної свідомості питанням науки і освіти в Україні? Безумовно!

Чому ж головні проблеми не розв'язані? Чи готує людину до їх розв'язання сучасна освіта?

Сто років тому головним завданням освіти було навчити людину грамотності. Так званий «знаннєвий» підхід був необхідним і виправданим. Але зараз, коли розвиток людства катастрофічно відстає від розвитку технологій, освіта має повернутися обличчям до самої людини. Вона має стати «олюдненою».

Анкетування, проведене серед дорослих, засвідчило, що в повному обсязі шкільна програма знадобилася лише $6 \%$ респондентів.

Як має бути структурована інноваційна шкільна програма? Діти мають право на фізичний розвиток, розвиток спілкування, емоцій і почуттів, моральний і творчий розвиток. Нарешті, на розвиток свідомості - ідеалів, смислів і цінностей. Саме на це має бути спрямований освітній процес. Для того, щоби досягти миру в країні, слід розвивати толерантність, діалогічність, стверджувати цінність життя і здоров'я.

Для подолання корупції слід виховувати чесність, прагнення служити людям, відповідальність.

Для зміцнення здоров'я та збільшення тривалості життя слід формувати відповідальне ставлення до власного організму, залучати до здорового способу життя.

Нарешті, для збереження природи слід розвивати екологічну свідомість, планетарне мислення.

Чи не $є$ ці всі завдання завданнями освіти? Чи не настав час розглядати війни, корупцію і стан екології як наслідок низького рівня свідомості сучасної людини?

Справжні інновації в освіті потребують переходу від знаннєво-репродуктивної парадигми до нової парадигми розвитку свідомості особистості. У нашому дослідженні ми спиралися на 5-рівневу модель розвитку свідомості, де:

1 рівень характеризується усвідомлення цінності життя та здоров'я;

2 рівень - сімейні цінності, єдність подружжя, повага і взаємодія у сім'ї;

3 рівень - громадянські цінності, соборність, любов до своєї країни, звичаї і традиції народу;

4 рівень - загальнолюдські цінності, усвідомлення єдності людства, повага, толерантність, діалогічність;

5 рівень - відповідальність за природу, усвідомлення єдності світу, в якому ми живемо.

Навчання, спрямоване на розвиток свідомості людини, має наскрізно пронизувати систему освіти та об'єднувати громадян країни, у тому числі на територіях, які наразі не є підконтрольними. Але підконтрольність - не єдина функція держави. Саме освіта може долати кордони розмежування і непорозуміння.

Прикладом освітніх інновацій, розроблених на вказаних засадах, є інтегративний курс «Людина. 
Родина. Світ», створений у співпраці Інституту педагогічної освіти і освіти дорослих імені Івана Зязюна НАПН України, Інституту проблем виховання НАПН України, Мелітопольського державного педагогічного університету імені Богдана Хмельницького та Благодійного фонду «Людина. Родина. Країна». Наразі цей проект охоплює 80 закладів освіти в Україні й 2 - за кордоном. 398 педагогів проходять підготовку до викладання курсу на семінарах і тренінгах.

Ще один стартап - Дистанційна школа демократії та громадянського суспільства, започаткована спільно з Українським науково-методичним центром практичної психології і соціальної роботи. Програма школи була надіслана Президенту України і отримала схвальну оцінку Верховної Ради України.
Переконані, що Національна академія педагогічних наук України робить надзвичайно багато, однак для того, щоби суспільство повернувся обличчям до науки, ми як учені, маємо забезпечити психологічний супровід соціально значущих інноваційних процесів в освіті.

Для цього пропонуємо:

1. Сфокусувати наукові дослідження на розв'язанні головних суспільних проблем, серед яких війна, корупція, здоров'я людини і екологія планети.

2. Здійснити "олюднення» освіти. Ввести до основних програм обов'язкові предмети, які забезпечують розвиток людини, її свідомості, а не окремої здатності обслуговувати роботизований світ.

Дякую за увагу!

\section{DEVELOPMENT OF PERSONALITY'S CONSCIOUSNESS AS A STRATEGIC AIM OF MODERN EDUCATION Scientific report at the General Meeting of the National Academy of Educational Sciences of Ukraine, December 17, 2019}

\section{Eduard Pomytkin}

DSc in Psychology, Professor, Head of the Psychology of Labour Department, Ivan Ziaziun Institute of Pedagogical and Adult Education of the National Academy of Educational Sciences of Ukraine, Kyiv, Ukraine

Abstract. The problem of education modernization through the transition from the knowledge and reproductive paradigm to the new paradigm of personality's consciousness development are actualized. In this context the wars, corruption and the state of the environment in Ukraine are seen as s consequence of a low level of human consciousness. The integrative course "Human. Family. World", the E-Learning School for Democracy and Civil Society are presented as the example of education innovations developed on the mentioned grounds.

Keywords: personality; consciousness; development; education modernization. 